\title{
TEORI KESEIMBANGAN UMUM DALAM EKONOMI ISLAM
}

\author{
Ainun Nurul Sya'diah \\ Pascasarjana UIN Sunan Gunung Djati Bandung \\ e-mail : ainunnsyadiah@gmail.com
}

\begin{abstract}
ABSTRAK
Penelitian ini menguraikan bahasan singkat mengenai teori keseimbangan umum dalam Islam yang membahas bagaimana keseimbangan pasar dengan syariat Islam yang berlaku, serta proses penerapan didalamnya. Pembahasannya menunjukkan pola kebijakan dan peradaban ekonomi dalam Islam serta hubungannya dengan keseimbangan umum di dalam pasar yang dikhususkan menurut syariat Islam. Penelitian ini menggunakan metode kualitatif dengan pedekatan deskriptif. Hasil dari penelitian ini terdapat beberapa teori yang menunjukan keseimbangan umum khususnya keseimbangan pasar dengan mekanisme pasar dalam Islam sebagai suatu keseimbangan dan keadilan antara permintaan dan penawaran.
\end{abstract}

Kata Kunci : Keseimbangan Umum, Pasar, Ekonomi Islam 


\section{PENDAHULUAN}

Agama diturunkan di muka bumi sebagai petunjuk bagi manusia yang didalamnya manusia-manusia tersebut akan menjalankan berbagai kegiatan termasuk ekonomi baik dalam lingkup yang makro maupun mikro. dalam ruang lingkup mikro, akan dapat ditemukan berbagai transaksi ekonomi individu yang satu dengan individu lainnya yang seharusnya sesuai dengan aturan yang ada karena Islam hadir dengan seperangkat aturannya termasuk mengatur bagaimana perekonomian didalamnya.

Ekonomi Islam termasuk ilmu ekonomi yang dikembangkan berdasarkan nilai-nilai Islam. (Suprihatin, 2017) jika sebuah perekonomian negara yang di dalamnya beragamakan Islam tidak menggunakan nilai-nilai Islam, maka telah terjadi kesalahan disana dan tidak bisa dikatakan sebagai perekonomian Ideal. Sebuah perekonomian ideal, tentunya harus mampu berkompetitif sempurna dimana pengaturan alokasi sumber daya bersumber dari pertukaran sukarela antara barang dan uang pada harga pasar yang akan menghasilkan kuantitas maksimum barang dan jasa dari segenap sumber daya yang tersedia dalam perekonomian tersebut. (Hidayatullah, 1996)

Dalam kegiatan pasar yang modern saat ini, telah terjadi pergeseran tentang mekanisme pasar, ada ketidakstabilan harga yang dipermainkan oleh sectorsektor tertentu dan menaik turunkan harga secara personal. Tidak adanya kejujuran, persaingan yang sehat dan adil, keterbukaan, dan keadilan, sehingga mekanisme pasar tidak lagi berjalan dengan semestinya yang dipentingkan hanyalah keuntungan saja. Mekanisme pasar dalam Islam adalah suatu keseimbangan dan keadilan antara permintaan dan penawaran. Secara garis besar mekanisme pasar dalam Islam adalah kebebasan dalam menentukan harga dilihat dari keseimbangan pasar dimana hal tersebut berguna untuk menstabilkan antara permintaan dan penawaran dalam kemaslahatan umat manusia.

Dalam penelitian Amiral mengenai perbandingan ekonomi konvensional dan Islami mengemukakan bahwa: "Pasca perang dunia kedua, negara-negara di 
dunia mengalami masalah krisis dan problematika ekonomi yang sama di antaranya adalah inflasi, krisis moneter Internasional, problematika pangan, problematika hutang negara yang terus berkembang dan lain-lain." (Amiral, 2017) Hal ini disebabkan karena nilai-nilai Islam tidak ditearapkan dalam mengelola ekonomi, melainkan nilai-nilai barat lah yang menjadi tolak ukurnya.

Dari latar belakang tersebut, penulis tertarik untuk membahas artikel ini dengan judul "Teori Keseimbangan Umum dalam Ekonomi Islam".

\section{Metode Penelitian}

Penelitian ini menggunakan metode penelitian kualitatif deskriptif dengan teknik yang dipilih adalah studi kepustakaan. Dalam penelitian studi pustaka ini akan ada setidaknya 4 ciri di dalamnya, yang pertama peneliti akan melihat langsung teks atau datanya namun bukan dengan pengetahuan lapangan. Kedua, data pustaka akan bersifat langsung bisa digunakan oleh peneliti walaupun tidak terjun ke lapangan, "data pustaka umumnya adalah sumber sekunder" (Sugiyono, 2014) yang dalam hal ini peneliti mendapatkan nya atas penelitian sebelumnya, keempat bahwa kondisi dari "data pustaka tidak dibatasi oleh ruang dan waktu" (Sugiyono, 2012). Jenis penelitian melalui kepustakaan ini biasa disebut dengan library research atau penyelidikan kepustakaan.

\section{PEMBAHASAN}

\section{Konsep Dasar Keseimbangan Umum}

Analisis keseimbangan umum (general equilibrium) adalah analisis atau studi ekonomi yang mempelajari bagaimana kondisi penawaran (supply) dan permintaan (demand) berinteraksi dalam berbagai pasar secara simultan (Susilo, 1999). Adanya keseimbangan di suatu pasar merupakan bagian dari pembahasan ekonomi mikro. Ekonomi mikro konvensional mempelajari bagaimana perilakuperilaku individu dalam memenuhi kebutuhan maupun keinginannya yang didasarkan pada perilaku individuindividu yang secara nyata terjadi pada setiap unit ekonomi, di mana perilaku para pembeli dan penjual tersebut secara 
alamiah akan mendorong terciptanya harga dalam mekanisme pasar ke arah keseimbangan. Apabila harga pasar berada di atas harga keseimbangan maka akan terjadi kelebihan penawaran yang kemudian akan medorong harga pasar menurun, namun apabila harga pasar berada di bawah harga keseimbangan maka terjadilah kelebihan permintaan yang menyebabkan harga meningkat. (Muflihin, 2019)

Dalam keseimbangan umum, secara singkat memberikan penjelasan bagaimana sebuah sektor perekonomian berada dalam keseimbangan yang dibuktikan melalui permintaan dan penawarannya. Seluruh pelaku di pasar berperan sangat penting dalam proses keseimbangan ini, karena merekalah yang secara langsung menyeimbangkan anggaran mereka. Selanjutnya, harga keseimbangan akan ditentukan melalui mekanisme penawaran dan permintaan, harga yang terjadi ialah harga yang bersifat relatif bukan nominal dan mencerminkan harga konsumen agregat dan seragam di seluruh transaski pasar yang bersangkutan.

\section{Keseimbangan Umum dalam Islam}

Berbeda dengan ekonomi konvensional yang memiliki paradigma materialisme, ekonomi Islam merupakan pengetahuan yang dikembangkan berdasarkan akal dan wahyu yaitu al-Qur'an dan al-Hadits. (Suprihatin, 2017) Maka dalam melakukan kegiatan ekonomi Islam akan ada 2 aspek kebaikan yang mesti diamati yaitu nilai-nilai yang bersumber dari Allah SWT dan nilai-nilai kebaikan atas dasar fakta indrawi manusia, yang kemudian melahirkan etika sekaligus cara kerja yang baik.

Dalam teori keseimbangan pasti tidak akan terlepas dari teorinya Adam smith mengenai consumer equilibrium, namun dalam Islam, keseimbangan pun dijelaskan dengan berbagai dukungan lainnya salah satunya dijelaskan dalam Surat Al-Furqan Ayat 67 :

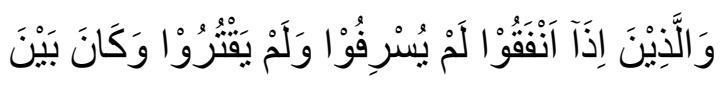

$$
\begin{aligned}
& \text { ذلِلِكَ قَوَامًا }
\end{aligned}
$$

“Dan (termasuk hamba-hamba Tuhan Yang Maha Pengasih) orang-orang yang apabila menginfakkan (harta), mereka tidak berlebihan, dan tidak (pula) kikir, di antara keduanya secara wajar" 
Menggunakan pendekatan unity konsumen, dan mampu mengatur approuch yang digagas Anas Zarqa', bagaimana kebutuhannya selama hidup Dalam kajian Ulumul Qur'an, ayat ini termasuk golongan ayat ayat makkiyah. Secara etimologis, al-Furqan berasal dari bahasa Arab berarti pembeda yang diambil dari bagian awal surat ini. Kata alFurqan di sini dimaksudkan sebagai kitab alQur'an itu sendiri. Dinamai demikian, karena alQur'an adalah pembeda antara yang hak dengan yang batil, antara yang benar dan yang salah. Pokok-poko isi surat ini adalah membicarakan tentang keimanan, hukum-hukum, kisah-kisah dan topik tentang kejadian alamiah sebagai bukti keesaan Allah SWT (Mochlasin, 2013)

Dari ayat Al-Furqan 67 tersebut keseimbangan yang muncul adalah ketika seorang muslim memiliki harta maka muslim hendaknya memlihara hartanya, tidak memboroskan sehingga habis, tetapi pada saat yang sama tidak dibolehkan menahannya sehingga mengorbankan kepentingan pribadi, keluarga, keluarga atau orang lain yang membutuhkan. Landasan ini menjadi hal yang penting dalam mengatur keseimbangan dari pihak di bumi.

Dalam ekonomi konvensional, kesimbangan umum dapat terjadi apabila pasar barang dan pasar uang ada di dalam keseimbangan. Dalam keadaan keseimbangan umum ini besarnya pendapatan nasional (Y) dan tingkat bunga (i) yang terjadi akan mencerminkan pendapatan nasional (Y) dan tingkat bunga (i) yang seimbang baik di pasar barang maupun di pasar uang (Solihin, 2019)

Dalam Islam memang tidak jauh dengan keseimbangan konvensional, selain adanya landasan yang utuh dari Al-quran dan Al Hadits, dalam Islam ada penghapusan tingkat bunga karena dilarang oleh agama, dan memberikan solusi dengan bagi hasil serta dengan tingkat keuntungan yang diingankan (r).

Kekhasan pertumbuhan dan pembangunan dalam ekonomi Islam ditekankan pada perhatian yang sangat serius pada pengembangan sumber daya manusia sekaligus pemberdayaan alam untuk meningkatkan harkat dan martabat manusia. Ini tidak hanya diwujudkan dalam 
keberhasilan pemenuhan kebutuhan material saja, namun juga kebutuhan dan persiapan menyongsong kehidupan akhirat. Jadi, ekonomi Islam lebih ditekankan pada suatu konsep dan usaha untuk dapat meningkatkan kesejahteraan masyarakat. Dengan demikian, ekonomi Islam adalah jawaban tantangan peradaban dunia. (Syaparuddin, 2010)

\section{Mekanisme Pasar untuk Mencapai}

\section{Keseimbangan}

\section{Permintaan}

Dalam ekonomi Islam, permintaan juga diakui sebagai elemen pasar. Timbulnya permintaan dilakukan dengan beberapa pendekatan. (Suprihatin, 2017) Pertama, berdasarkan konsep utilitas yang dikemukakan oleh Adiwarman (Karim, 2002) Kedua, analisis timbulnya permintaan berdasarkan maslahah yang dikemukakan cendekiawan Muslim P3EI UII. Konsep utilitas yang ditawarkan oleh Adiwarman Karim berlaku hanya pada permintaan barang halal. Jika terdapat pilihan barang halal dan haram baik yang bersifat substitutive maupun komplementer maka konsumen Muslim harus memilih pada barang yang halal.

Pencapaian kepuasan (utility) dilakukan dengan dua pendekatan yaitu dengan memaksimalkan anggaran pada suatu pendapatan atau dengan meminimalisasikan garis anggaran pada suatu pendapatan. (Karim, 2002) Menurut Adiwarman, proses terjadinya permintaan sama dengan penetapan permintaan yang dilakukan ekonomi konvensional, dimana pada harga yang tinggi kuantitas permintaan semakin menurun sementara pada harga yang rendah kuantitas permintaan akan semakin meningkat. Permintaan yang dilakukan konsumen dilakukan berdasarkan pada utilitas dari dua kombinasi barang atau jasa di pasar yang bersifat berubah-ubah dikarenakan adanya perubahan harga. Dari tiap perubahan harga menghasilkan titik utilitas yang diturunkan menjadi suatu garis permintaan. Di bawah ini akan diungkapkan ilustrasi Adiwarman Karim dalam menurunkan kurva permintaan pada barang halal. Misalkan A memiliki pendapatan Rp. 1.000 .000 per bulan 
diperuntukan mengkonsumsi barang 100.000 dan $Z=R p .200 .000$. Data tersebut halal $\mathrm{R}$ dan $\mathrm{Z}$ dengan harga $\mathrm{R}=\mathrm{Rp}$. ditunjukan dalam tabel berikut:

Tabel 1

Data Permintaan barang $\mathrm{R}$ dan Z harga 1

\begin{tabular}{ccccccc}
\hline $\begin{array}{c}\text { Kombinasi } \\
\text { Barang }\end{array}$ & Pendapatan & PR & PZ & R=1/PR & Z=1/PZ & X \\
\hline A & 1.000 .000 & 100.000 & 200.000 & 10 & 0 & at tange \\
\hline B & 1.000 .000 & 100.000 & 200.000 & 0 & 5 & 3 \\
\hline
\end{tabular}

Lalu misalkan terjadi penurunan sesuai dengan tabel yang dijelaskan harga R menjadi Rp.50.000 maka pastinya berikut :

jumlah penrimtaan $\mathrm{R}$ pun akan berubah

Tabel 2

Data Permintaan barang $\mathrm{R}$ dan $\mathrm{Z}$ harga 2

\begin{tabular}{lllllll}
\hline $\begin{array}{l}\text { Kombinasi } \\
\text { Barang }\end{array}$ & Pendapatan & PR & PZ & R=1/PR & Z=1/PZ & X \\
\hline A & 1.000 .000 & 50.000 & 200.000 & 20 & 0 & at tange \\
\hline B & 1.000 .000 & 50.000 & 200.000 & 0 & 5 & 4 \\
\hline
\end{tabular}


Selanjutnya ada penurunan lagi untuk barang $\mathrm{R}$ menjadi Rp. 25.000, maka akan dijelaskan dalam tabel berikut:

\section{Tabel 3}

Data Permintaan barang R dan Z harga 3

\begin{tabular}{lllllll}
\hline $\begin{array}{l}\text { Kombinasi } \\
\text { Barang }\end{array}$ & Pendapatan & PR & PZ & R=1/PR & Z=1/PZ & X \\
\hline A & 1.000 .000 & 50.000 & 200.000 & 40 & 0 & at tange \\
\hline B & 1.000 .000 & 50.000 & 200.000 & 0 & 5 & 5 \\
\hline
\end{tabular}

Data tersebut dapat dijadikan acuan untuk dalam membuat kurva berikut:

\section{Gambar 1. Kurva Permintaan barang R dan Z}

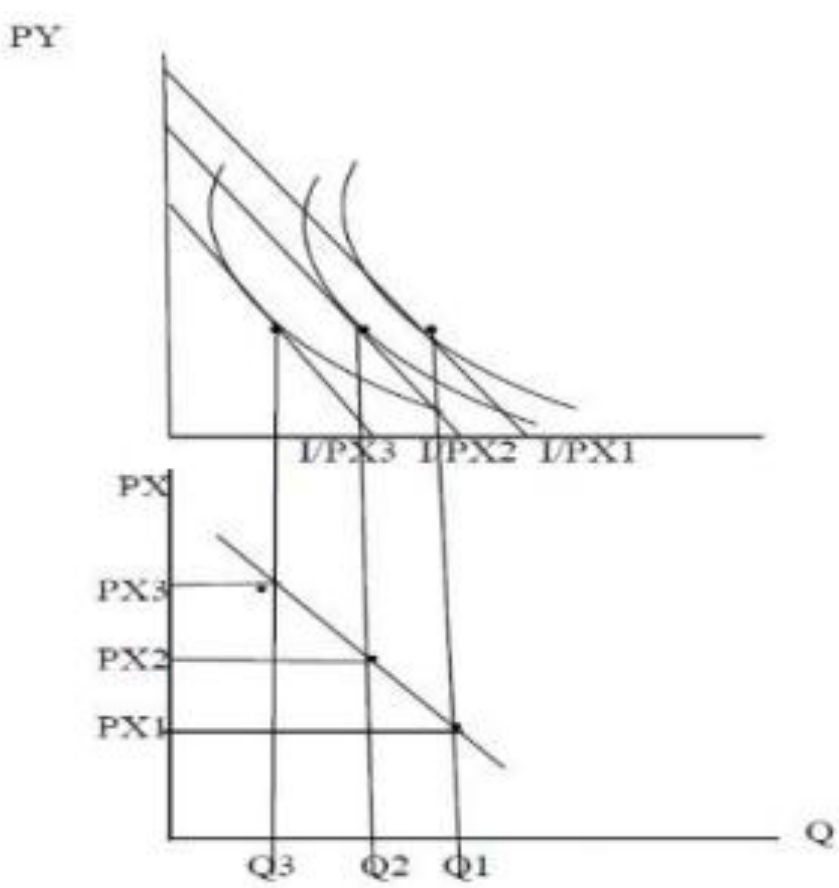

Selanjutnya konsep maslahah adalah manfaat yang mengandung berkah pada konsumsi. Keputusan melakukan permintaan harus dapat menghasilkan dua prefensi yaitu berkah dan kebermanfaatan. Kemampuan konsumen dalam mendayagunakan anggarannya pada kemaslahatan dapat dijadikan sebagai 
fondasi dalam melakukan permintaan di pasar, semakin rendah harga suatu barang, ceteris paribus, maka akan semakin tinggi jumlah permintaan, sebaliknya semakin tinggi harga suatu barang, ceteris paribus, maka akan semakin rendah jumlah permintaan.

Permintaan merupakan salah satu elemen yang menggerakkan pasar, istilah yang digunakan oleh Ibnu Taimiyah untuk menunjukkan permintaan ini adalah keinginan. Keinginan yang muncul pada konsumen sesungguhnya merupakan sesuatu yang kompleks, dikatakan berasal dari Allah. Namun, pada dasarnya ada faktor-faktor yang mempengaruhi permintaan ini, yaitu: harga barang yang bersangkutan, pendapatan konsumen, harga barang lain yang terkait, selera konsumen, ekspektasi (pengharapan), maslahah (tujuan dalam mengonsumsi barang). Permintaan ini juga tergambar dari kurva yang menunjukkan hubungan antara harga dan jumlah barang yang diminta. (Wulandari \& Zulqah, 2020)

\section{Penawaran}

Pasar dikenal sebagai tempat bertemunya permintaan dan penawaran suatu produk yang memiliki nilai tambah (Hijriah \& Adiba, 2019) selanjutnya, Definisi ini menurut Ibnu Taimiyah adalah kekuatan penting dalam pasar sebagai ketersediaan barang yang ada di pasar. Menurutnya penawaran bisa dari impor dan produksi lokal sehingga kegiatan ini dilakukan oleh produsen maupun penjual. Dalam pencapaian maslahah penawaran sendiri dibutuhkan keimanan yang ada pada diri produsen, apabila jumlah maslahah yang terkandung dalam barang yang diproduksi maka akan meningkatkan jumlah produksinya. (Rahmi, 2015)

Keseimbangan ekonomi adalah tujuan perekonomian. (Wicaksono, 2019) Dalam hal ini menyangkut bagaimana permintaan termasuk penawaran di dalamnya. Dalam teori Permintaan dan Penawaran dan dalam analisis kelakuan konsumen telah diterangkan interaksi diantara penjual dan pembali dalam menentukan jenis barang dan jumlah barang yang diperlukan diproduksikan. 
Analisis penawaran dengan pendekatan ekonomi mikro Islam banyak dibahas oleh cendekiawan Muslim, di antaranya adalah yang dikemukakan oleh Adiwarman Karim, Suatu produksi dikatakan maslahah apabila mengandung motivasi untuk mendapatkan untung tanpa melanggar syariat, serta mewujudkan kerja keras sebagai refleksi tawakkal. (Suprihatin, 2017)

Disamping itu produksi juga dikatakan maslahah apabila memiliki tujuan untuk :

1. Memenuhi kebutuhan manusia pada tingkatan moderat

2. Menemukan kebutuhan masyarakat dan pemenuhannya
3. Menyediakan persediaan barang/ jasa untuk masa depan

4. Pemenuhan sarana bagi kegiatan sosial dan ibadah pada Allah Swt.

Dengan demikian, focus maslahah yang harus dicapai oleh produsen adalah pada keuntungan. Fungsi maslahah bagi produsen dapat diformulasikan pada persamaan sebagai berikut :

$$
\begin{gathered}
\mathrm{M}=\Pi+\mathrm{B}, \mathrm{M}=\mathrm{TR}-\mathrm{TC}-\mathrm{BC}, \mathrm{M}= \\
\beta \mathrm{TR}
\end{gathered}
$$

Selanjutnya, Maksimalisasi Maslahah Produsen Asumsi harga Rp. 171 dengan rumus:

$$
\beta P \delta Q=\delta T C+\delta B
$$

Tabel 4

Data Penawaran harga 171

\begin{tabular}{lccccccc}
\hline $\mathbf{Q}$ & $\delta \mathrm{Q}$ & $\boldsymbol{\beta P}$ & $\mathrm{TC}$ & $\delta \mathrm{TC}$ & $\mathrm{BC}$ & $\delta \mathrm{BC}$ & $\delta \mathrm{STC}+$ \\
\hline $\mathbf{1}$ & 1 & 171 & 140 & 18 & & 171 & \\
\hline $\mathbf{2}$ & 1 & 171 & 145 & 20 & 20 & 171 & 165 \\
\hline $\mathbf{3}$ & 1 & 171 & 291 & 41 & 21 & 171 & 167 \\
\hline $\mathbf{4}$ & 1 & 171 & 293 & 43 & 22 & 171 & 169 \\
\hline
\end{tabular}




\begin{tabular}{llllllll}
\hline 5 & 1 & 171 & 295 & 45 & 23 & 171 & 171 \\
\hline 6 & 1 & 171 & 297 & 47 & 24 & 171 & 173 \\
\hline 7 & 1 & 171 & 299 & 49 & 25 & 171 & 175 \\
\hline
\end{tabular}

Sumber : Cendekiawan P3EI UII, Ekonomi Islam

Berdasarkan data di atas, maka produksi yang mengandung maslahah maksimum ada pada tingkat produksi 5 unit, pada saat memproduksi 5 unit, nilai tambahan pendapatan dari hasil produksi unit terakhir tepat sama dengan jumlah biaya produksi dan biaya berkah. Jika produsen memproduksi di atas 5 unit, maka akan mengalami kerugian. Apabila harga dari Rp. 171 sebagaimana data di atas dinaikkan menjadi Rp. 181, sementara semua hal lain diasumsikan tetap sama (ceteris paribus), maka dapat diperoleh data sebagai berikut :

Tabel 5

Data Penawaran harga 181

\begin{tabular}{|c|c|c|c|c|c|c|c|}
\hline $\mathbf{Q}$ & $\delta Q$ & $\beta \mathbf{P}$ & $\mathrm{TC}$ & $\delta \mathrm{TC}$ & BC & $\delta B C$ & $\begin{array}{r}\delta T C \\
+\delta B C\end{array}$ \\
\hline 1 & 1 & 181 & & 18 & & 181 & \\
\hline 2 & 1 & 181 & 145 & 20 & 20 & 181 & 165 \\
\hline 3 & 1 & 181 & 146 & 41 & 21 & 181 & 167 \\
\hline 4 & 1 & 181 & 147 & 43 & 22 & 181 & 169 \\
\hline 5 & 1 & 181 & 148 & 45 & 23 & 181 & 171 \\
\hline 6 & 1 & 181 & 149 & 47 & 24 & 181 & 173 \\
\hline 7 & 1 & 181 & 150 & 49 & 25 & 181 & 175 \\
\hline
\end{tabular}

Sumber : Cendekiawan P3EI UII, Ekonomi Islam 
Berdasarkan data di sebelumnya, maka produksi yang mengandung maslahah maksimum ada pada tingkat produksi 10 unit, pada saat memproduksi 5 unit, nilai tambahan pendapatan dari hasil produksi unit terakhir tepat sama dengan jumlah biaya produksi dan biaya berkah. Jika produsen memproduksi di atas 10 unit, maka akan mengalami kerugian, Berdasarkan data di atas dapat diturunkan pada kurva penawaran sebagai berikut :

Gambar 2

Kurva Penawaran

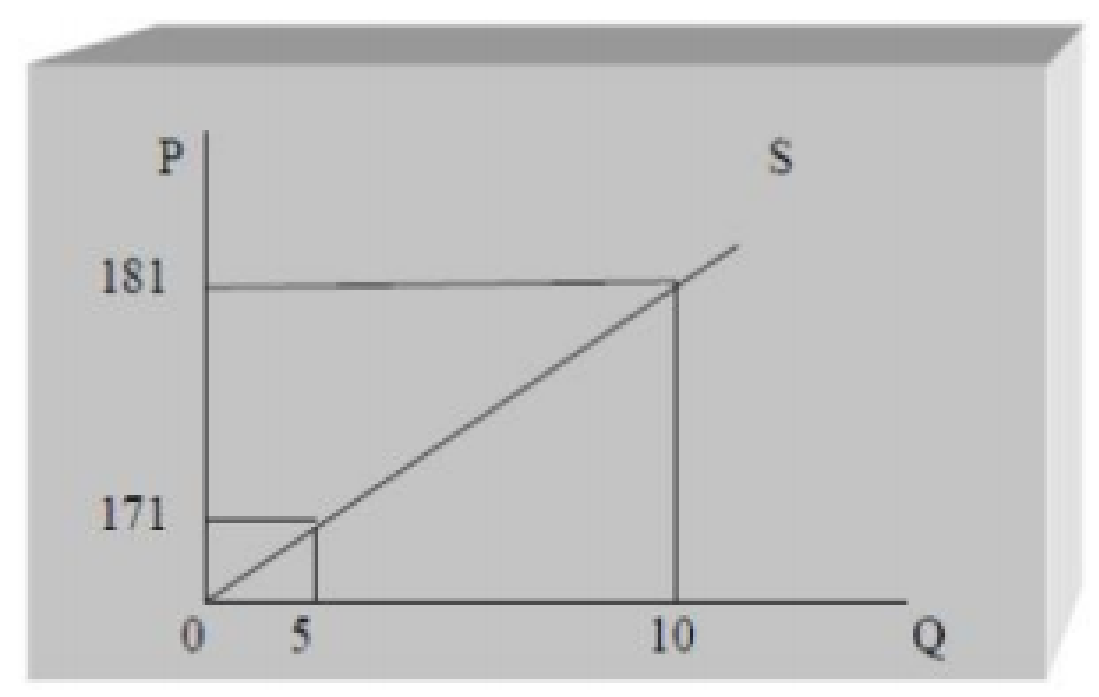

\section{SIMPULAN}

Pasar dalam perspektif ekonomi Islam merupakan sebuah institusi atau prosedur yang didalamnya ada hubungan ekonomi sekaligus hubungan sosial antar individu yang melibatkan jasa dan barang. Keseimbangan dalam pasar menjadi salah satu tujuan untuk mencapai idealitas perekonomian suatu negara, dimana permintaan dan penawaran berada dalam titik keseimbangan tersebut. Dalam Islam, selain bunga dilarang, ada berkah dan manfaat atau maslahah lainnya yang diutamakan dalam proses permintaan dan penawaran. Nilai-nilai yang dilakukan didalamnya harus ada dalam ruang 
lingkup halal, utilitas, maslahah dan suatu barang. Keseimbangan umum keadilan. Terdapat berbagai keinginan dalam ekonmi Islam diletakan pada konsumen yang perlu disesuaikan, namun keseimbangan di teori pada umumnya prinsip Islam telah mengaturnya yang diperbaiki kemudian dibaluti nilaitermasuk bagaimana proses mengatur nilai Islam di dalamnya.

keinginan membeli ataupun menjual 


\section{DAFTAR PUSTAKA}

Amiral. (2017). Perbandingan Ekonomi Konvensional Dan Ekonomi Islam. Iqtishodiyah, 5(2), 148-162.

Hidayatullah, I. (1996). Peran Pemerintah dalam Ekonomi Pasar Terbuka. Unisia, 16(31), 17-22. https://doi.org/10.20885/unisia.vol16.iss31.art2

Hijriah, H. Y., \& Adiba, E. M. (2019). The Labor Market: An Overview from an Islamic Perspective. TIJAB (The International Journal of Applied Business), 3(1), 24. https://doi.org/10.20473/tijab.v3.i1.2019.24-37

Karim, A. (2002). Ekonomi Mikro Islam (IIT).

Mochlasin, M. (2013). Rekonstruksi Teori Consumer Equilibrium Perspektif Ekonomi Islam. Muqtasid: Jurnal Ekonomi Dan Perbankan Syariah, 4(1), 107. https://doi.org/10.18326/muqtasid.v4i1.107-129

Muflihin, M. D. (2019). Permintaan, Penawaran Dan Keseimbangan Harga Dalam Prespektif Ekonomi Mikro Islam. JES (Jurnal Ekonomi Syariah), 4(2), 185-195. https://doi.org/10.30736/jesa.v4i2.68

Rahmi, A. (2015). Mekanisme Pasar dalam Islam. Jurnal Ekonomi Bisnis Dan Kewirausahaan, 4(2), 177. https://doi.org/10.26418/jebik.v4i2.12481

Solihin, B. (2019). Konsep Mekanisme Pasar dan Persaingan Harga Dalam Islam. Jurnal Ilmu-Ilmu Agama, 1(2), 25-34.

Sugiyono. (2012). Metode Penelitian Kuantitatif Kualitatif dan RED. Alfabeta.

Sugiyono. (2014). Metode Penelitian Kuantitatif, Kualitatif, dan Kombinasi (Mixed Methods). Alfabeta.

Suprihatin. (2017). Model Dasar Konsep Pasar Dalam Perspektif Ekonomi Islam. Al Intaj, 3(1), 71-84.

Susilo, S. Y. (1999). Model Keseimbangan Umum Terapan: Suatu Gambaran Umum.4(1), 1- 
10.

Syaparuddin. (2010). Ekonomi Islam: Solusi terhadap Berbagai Permasalahan SosialEkonomi. Muqtasid, 1(1), 1-19.

https://muqtasid.iainsalatiga.ac.id/index.php/muqtasid/article/download/2/2

Wicaksono, J. W. (2019). Relevansi Model IS-LM Keseimbangan Pasar Barang dan Pasar Uang dalam Islam. Dinar, 3(1), 1-29.

Wulandari, C., \& Zulqah, K. A. (2020). Tinjauan Islam terhadap Mekanisme Pasar dan Penanganan Distorsinya. Journal of Islamic Economics and Finance Studies, 1(1), 82. https://doi.org/10.47700/jiefes.v1i1.1923 
Ainun Nurul Sya'diah 